\title{
Eksposisi Kepemimpinan Musa Berdasarkan Keluaran 17:1-7 Dan Implikasi Bagi Kepemimpinan Hamba Tuhan Masa Kini
}

\author{
Frenly Charles Satria Tiwa
}

\begin{abstract}
Abstrak
Tujuan penulisan skripsi ini adalah untuk menemukan kepemimpinan Musa yang seperti apa yang ada dalam Keluaran 17:1-7 dan menjelaskan implikasi dari kepemimpinan Musa bagi kepemimpinan hamba Tuhan masa kini. Berdasarkan penelitian yang dilakukan maka kesimpulan yang diambil adalah sebagai berikut: Pertama, Kepemimpinan yang berjalan dengan titah Tuhan. Musa adalah seorang pemimpin, yang dalam kepemimpinannya berjalan sesuai dengan titah TUHAN. Dalam Keluaran 17:1 menjelaskan tentang bagaimana Musa menjalankan roda kepemimpinan terhadap bangsa Israel sesuai dengan titah TUHAN. Kepemimpinan Hamba Tuhan harus selalu berjalan sesuai dengan titah Tuhan sehingga apapun yang dijalankan di dalam kepemimpinan tersebut tidak terlepas dari campur tangan Tuhan. Kedua, Kepemimpinan tidak terlepas dari masalah dan tekanan yang dating dari orang yang dipimpin, dalam Keluaran 17:2-3 Musa mendapat masalah dan tekanan yang dating dari bangsa Israel. Sebagai Hamba Tuhan dalam memimpin jemaat yang dipimpin harus lebih mengerti bahwa kepemimpinan itu selalu ada tantangan dan hambatan. Ketiga, Kepemimpinan harus tahu mencari solusi yang benar untuk keluar dari masalah yang dihadapi yaitu dengan mencari kehendak Allah. Dalam Keluaran 17:4 bagaimana Musa mencari solusi yang benar dengan dating mencari kehendak Allah. Sebagai seorang pemimpin hal yang harus dilakukan sebelum bertindak untuk jemaat yang dipimpin harus bertanya kepada Tuhan dengan kata lain mencari kehendak Allah terlebih dahulu. Keempat, Sebagai Pemimpin seorang Hamba Tuhan harus mempunyai relasi yang baik dengan Tuhan agar supaya apa yang menjadi titah Tuhan dalam kepemimpinan tersebut dilakukan persis seperti apa yang Tuhan mau. Kelima, Selalu ada jawaban Tuhan kepada Pemimpin yang mengandalkan Tuhan. Dalam Keluaran 17:5-6a menjelaskan ada jawaban TUHAN terhadap Musa. Jadi ketika pemimpin yang bertanya pada Tuhan pasti selalu ada janji Tuhan di dalamnya atau dengan kata lain selalu ada jawaban dari Tuhan untuk dilakukan pemimpin tersebut. Keenam, Kepemimpinan yang melakukan Firman Tuhan. Dalam Keluaran 17:6b-7 menjelaskan bahwa Musa melakukan apa yang difirmankan TUHAN. Jadi sebagai pemimpin setiap Hamba Tuhan bukan hanya
\end{abstract}


mendengarkan suara Tuhan saja tetapi juga harus melakukan akan Firman itu dalam kepemimpinan yang dijalankannya itu kepada jemaatnya. Ketujuh, Secara keseluruhan kepemimpinan yang ada dalam Keluaran 17:1-7 adalah kepemimpinan teokratik di mana sang pemimpin Kristen bukanlah penguasa atau tuan bagi setiap orang yang dipimpin. Tetapi harus sadar bahwa kepemimpinan itu adalah kepemimpinan Allah yang sedang pemimpin itu jalankan. Jadi harus senantiasa taat dan patuh akan setiap perintah Allah, yang adalah pemimpin Agung. Jadi sebagai Hamba Tuhan di dalam kepemimpinannya, harus senantiasa sadar bahwa Hamba Tuhan dia ada di bawah kendali Allah.

Kata-kata Kunci: Kepemimpinan, Musa, Keluaran 17:1-7, Hamba Tuhan.

\section{Pendahuluan}

\section{Latar Belakang Masalah}

Manusia adalah makhluk sosial yang tidak bisa hidup tanpa orang lain, di mana manusia itu sendiri perlu berinteraksi dengan orang lain, baik itu kelompok, komunitas, organisasi, atau pun persekutuan. Dalam berorganisasi atau berkelompok pasti akan menemukan banyak perbedaan seperti perbedaan umur, tingkat pendidikan, dan karakter. Dengan adanya perbedaan-perbedaan seperti ini bisa menimbulkan konflik satu dengan yang lain baik itu konflik antar kelompok maupun individu yang ada didalam kelompok itu sendiri. Konflik seperti ini terjadi karena setiap individu yang ada di dalamnya lebih mementingkan keegoisan diri sendiri tanpa memikirkan akan anggota yang ada, sehingga banyak terjadi konflik dalam satu kelompok, organisasi atau komunitas.

Dengan melihat realitas di atas, maka kepemimpinan itu sangat penting dan sangat diperlukan untuk dibahas dan dilakukan dalam kehidupan manusia. Karena dengan adanya kepemimpinan maka komunitas, kelompok, organisasi atau persekutuan akan lebih teratur, lebih baik, dan memiliki tujuan yang jelas karena ada yang mengarakan di dalamnya yaitu pemimpin itu sendiri. Tugas pemimpin adalah menggerakan, mengatur, dan meluruskan akan permasalahan, dan apa yang akan dicapai itulah sebabnya kenapa kepemimpinan dikatakan suatu proses dengan berbagai cara untuk mempengaruhi orang. ${ }^{1}$ Hal ini juga bisa kita lihat dalam Amsal 11:14a, "Jika tidak ada pemimpin, jatuhlah bangsa" melihat akan ayat ini menjelaskan kepada kita bahwa kepemimpinan itu sangat berpengaruh dalam suatu organisasi dan bangsa. Jan Hendriks seorang pakar dalam bidang Pembangunan Jemaat mengajukan teori tentang lima faktor yang berarti bagi vitalitas sebuah jemaat. Salah satu faktor yang dipaparkan adalah kepemimpinan artinya jika kepemimpinan itu baik maka baik pula orang atau

\footnotetext{
${ }^{1}$ Charles J. Keating, Kepemimpinan: Teori dan pengembangannya (Yogyakarta: Kanisius, 1988), 9.
} 
organisasi yang dipimpin, sebaliknya jika kepemimpinan tidak baik maka tidak baik pula orang yang dipimpin. Sehingga memang benar kepemimpinan ini sangat penting dalam suatu organisasi baik itu sekuler maupun organisasi gereja yaitu kepada jemaat. Jika pemimpin dalam jemaat itu yang dalam hal ini hamba Tuhan yang dipercayakan mempunyai kepemimpinan yang baik, maka jemaat yang dipimpinnya akan menjadi baik, baik itu secara jasmani maupun rohani. ${ }^{2}$

Banyak hamba Tuhan yang baik dalam menjalankan roda kepemimpinannya tetapi di sisi lain ada banyak hamba Tuhan yang mengalami kemerosotan sehingga menjalankan kepemimpinan itu dengan tidak baik bahkan ada yang mundur dari kepemimpinan tersebut. Sebagai contoh dalam artikel yang ditulis oleh Amos Winarto yang berjudul kejatuhan hamba Tuhan. menuliskan dalam satu kota yaitu di Orlando Florida, ada tiga pendeta senior (Pemimpin Gereja) dari gereja yang sangat besar mengalami kegagaan dalam menjalankan roda kepemimpinan tersebut. Yang pertama, Isaac Hunter, gembala sidang Summit Church, mengundurkan diri pada bulan Desember 2012 setelah dia mengakui bahwa dia berhubungan gelap dengan seorang staff gereja. Kedua, Sam Hinn, gembala sidang gereja Gathering Place Worship Center, turun tahta di bulan Januari 2013 setelah mengakui hubungan gelap dengan jemaatnya. Yang ketiga, pada Bulan Mei 2015 David Loveless mengundurkan diri dari gereja Discovery Church setelah juga mengakui memiliki suatu hubungan gelap. ${ }^{3}$ Ini sebagian contoh yang bisa di lihat bagaimana kepemimpinan hamba Tuhan ketika menjalankan kepemimpinan dengan tidak benar maka akhirnya pemimpin tersebut bukan menjadi berkat tetapi jatuh. Contoh yang ada di atas juga di perkuat dengan data yang ditulis oleh George Barna, dia menjelaskan bahwa "setelah melakukan penelitian selama 15 tahun terhadap kehidupan gereja, akhirnya dia mengambil suatu kesimpulan alasan kenapa gereja kehilangan akan pengaruhnya dikarenakan tidak ada kepemimpinan yang baik dari hamba Tuhan tersebut."4 Ini memperlihatkan bagaimana hamba Tuhan tersebut melayani Tuhan tidak dengan teratur, sopan dan disiplin dalam menjalankan pelayanannya sehingga tidak menghasilkan buah yang baik dalam pelayanan terhadap orang yang dipimpin. Dalam sebuah artikel yang berjudul Kejatuhan Para Pemimpin Awal Kemunduran Gereja menjelaskan bahwa Gereja-gereja banyak yang pecah buka karena perbedaan dalam memahami kehendak Tuhan, bukan karena perbedaan dalam memperjuangkan kebenaran Tuhan, tetapi pecah karena ambisi pribadi yang tidak

\footnotetext{
${ }^{2}$ Jan Hendriks, Jemaat Vital dan Menarik: Membangun Jemaat dengan Menggunakan Metode Lima Faktor (Yogyakarta: Kanisius, 2002), 39.

${ }^{3}$ Amos Winarto, "Kejatuhan Hamba Tuhan"diakses 17 Juni 2016, http://sttaletheia.ac.id/?p=1781.

${ }^{4}$ Sen Sendjaya, Kejatuhan Pemimpin Gereja dan Cara Pencegahannya (Yogyakarta: ANDI, 2006), 360.
} 
suci dan tamak akan kekuasaan dari pemimpinnya. ${ }^{5}$ Di sini bisa dilihat bahwa pelayanan yang dilakukan oleh hamba Tuhan tersebut tidak sopan dan teratur dengan kata lain tidak suci dan kudus. Kalau melihat 1 Korintus 14:40 dikatakan bahwa, Tetapi segala sesuatu harus berlangsung dengan sopan dan teratur. Jika melihat akan ayat ini dan dikaitkan dengan kepemimpinan maka seorang pemimpin harus disiplin sopan dan teratur dalam pelayanannya baik pelayanan kepada anggota jemaat maupun hubungan kepada Allah.

Salah satu alasan mengapa penulis mencoba mengambil kepemimpinan dari pribadi Musa dan kenapa harus Musa. Ini dikarenakan penulis melihat bahwa kepemimpinan Musa adalah pemimpinan yang mengandalkan Tuhan untuk menjalankan misi Tuhan lewat dirinya sendiri, yaitu membawa Bangsa Israel keluar dari tanah Mesir. Salah satu juga yang menjadi alasan kenapa penulis mengambil dari kepemimpinan Musa dikarenakan Musa adalah pemimpin yang setia. Bahkan dalam Perjanjian Baru dalam surat Ibrani 3:2 dijelaskan bahwa Musa adalah pemimpin yang setia. Setia dalam segenap rumah-Nya. Dengan kata lain pelayanannya kepada Tuhan khususnya untuk memimpin bangsa Israel keluar dari tanah pebudakan yaitu tanah Mesir. Alasan kenapa penulis menulis kepemimpinan Musa diambil dari kitab Keluaran karena penulis melihat bahwa Kitab Keluaran menunjukkan bagaimana Tuhan memiliki hubungan secara pribadi dengan Musa. Tuhan sangat sabar terhadap keraguan Musa akan kepemimpinan dan akhirnya dia menjadi tidak ragu dengan Tuhan. Kitab Keluaran juga mendefinisikan jati diri bangsa Israel sebagai umat pilihan Allah. Mereka hidup bersama dalam masa-masa yang sulit, mengalami pembebasan dan berkat yang dasyat, tetapi yang paling penting adalah mereka melihat pekerjaan Tuhan dalam kehidupan mereka terus-menerus. Kitab Keluaran banyak menceritakan tentang Musa bahkan dalam buku-buku tafsiran banyak penulis dan ahli-ahli yang menafsirkan akan kitab ini sehingga penulis lebih banyak memiliki pemikiran dan perbandingan untuk menuangkan kedalam skripsi ini. itulah alasan kenapa penulis mengambil dari Keluaran. Melihat akan hal-hal yang telah tertulis di atas khususnya dalam kepemimpinan maka penulis terdorong untuk mengangkat akan judul ini khususnya dari kepemimpinan Musa. Walaupun Musa tidak sampai masuk ke tanah Kanaan yang adalah tanah perjanjian Allah tetapi Musa adalah pemimpin yang berperan penting ketika bangsa Israel keluar dari tanah perbudakan yaitu tanah Mesir.

Perkembangan zaman yang terjadi memang banyak membawah perubahan-perubahan terhadap manusia. Khususnya dalam hal bagi anak Tuhan yang belum memiliki pemahaman dan iman yang kuat sehingga banyak terjerumus dalam dosa-dosa baik itu narkoba, seks bebas, minuman keras dan

5 Binsar, "Kejatuhan Para Pemimpin Awal Kemunduran Gereja”, diakses 17 Juni 2016, http://mellowgracea.blogspot.co.id/2010/10/kejatuhan-para-pemimpin-awal-kemunduran_23.html 
lain-lain. Sehingga ini membutuhkan pemimpin yang lembut (Bil.12:3), dan tegas seperti Musa, dimana juga mempunyai hubungan yang baik dengan Tuhan, dengan mempunyai hubungan yang baik dengan Tuhan maka sikap hidup akan menjadi lebih baik sehingga apa yang disampaikan sesuai dengan apa yang dihidupinya dan pemimpin atau hamba Tuhan tersebut pun tidak ikut terjerumus dalam dosa.

\section{Pokok Masalah}

Bersarkan latar belakang di atas maka pokok masalah yang akan dibahas dalam penulisan skripsi ini adalah:

Pertama, Kepemimpinan Musa yang seperti apa yang ada dalamkitab Keluaran 17:1-7?

Kedua, Bagaimana Implikasi Kepemimpinan Musa bagi kepemimpinan hamba Tuhan masa kini?

\section{Tujuan Penelitian}

Adapun tujuan dari penulisan skripsi ini antara lain:

Pertama, Untuk menemukan kepemimpinan Musa yang seperti apa yang ada dalam Keluaran 17:1-7.

Kedua, Untuk menjelaskan implikasi dari kepemimpinan Musa bagi kepemimpinan hamba Tuhan masa kini.

\section{Manfaat Penelitian}

Adapun manfaat penulisan yang ingin dicapai melalui skripsi ini adalah:

Pertama, Agar para hamba Tuhan dapat mengetahui Kepemimpinan Musa yang seperti apa yang ada dalam Keluaran 17:1-7.

Kedua, Agar lewat skripsi ini para hamba Tuhan dapat mengetahui tentang kepemimpinan Musa berdasarkan Keluaran 17:1-7 dan dapat mengaplikasikannya dalam kepemimpinan hamba Tuhan masa kini.

Ketiga, Sebagai syarat untuk menyelesaikan program S1 di Sekolah Tinggi Theologia Jaffray Makassar.

\section{Metode Penelitian}

Metode penulisan yang dipakai didalam skipsi ini adalah metode kualitatif dengan menggunakan prinsip-prinsip hermeneutik metode eksegesis Alkitab. ${ }^{6}$ Penulis menggunakan teknik pengumpulan data melalui kepustakaan yaitu dengan menggunakan Alkitab dalam berbagai macam cetakan, Kamus, Tafsiran-tafsiran,

${ }^{6}$ Hengki Wijaya, Analisis Data Kualitatif: Ilmu Pendidikan Teologi (Makassar: Sekolah Tinggi Theologia Jaffray, 2018), 95. 
dan buku-buku serta dari berbagai literature dan tulisan yang ada di media online yang berhubungan dengan pembahasan skripsi yang penulis angkat ini.

\section{Batasan Penelitian}

Dalam skripsi ini penulisan hanya membahas kepemimpinan Musa berdasarkan Keluaran 17:1-7 dan implikasinya bagi kepemimpinan hamba Tuhan masa kini.

\section{Kepustakaan}

Hendriks, Jan. Jemaat Vital dan Menarik: Membangun Jemaat dengan Menggunakan Metode Lima Faktor. Yogyakarta: Kanisius, 2002.

Keating, Charles J. Kepemimpinan: Teori dan pengembangannya. Yogyakarta: Kanisius, 1988.

Lola, S., Petronella Tuhumury. "Prinsip-Prinsip Kepemimpinan Transformatif Berdasarkan Kitab Nehemia dan Implikasinya Bagi Kepemimpinan Rohani Masa Kini." Jurnal Jaffray 8, no. 2 (2010). http://dx.doi.org/10.25278/ji71.v8i2.48

Riswanto, D., Jermia Djadi. "Prinsip-Prinsip Kepemimpinan Yusuf Dalam Menghadapi Perubahan Berdasarkan Kitab Kejadian 37-50." Jurnal Jaffray 8, no. 2 (2010). http://dx.doi.org/10.25278/ji71.v8i2.46

Sendjaya, Sen. Kejatuhan Pemimpin Gereja dan Cara Pencegahannya. Yogyakarta: ANDI, 2006.

Wijaya, Hengki. Analisis Data Kualitatif: Ilmu Pendidikan Teologi. Makassar: Sekolah Tinggi Theologia Jaffray, 2018.

Winarto, Amos. "Kejatuhan Hamba Tuhan.” Diakses 17 Juni 2016. http://sttaletheia.ac.id/?p=1781.

Yuliastomo, N., Ivan Th.J Weismann. "Kepemimpinan Gembala: Suatu Kajian Filosofis tentang Proses Integrasi Kepemimpinan Rohani dan Sekuler." Jurnal Jaffray 8, no. 1 (2010). http://dx.doi.org/10.25278/jj71.v8i1.38 